計算にも納得のいかない点を残していた。 そこで，フィ ルム法を用いて，対向二閒照射をした場合と一門照射を した場合の比較をし，接線照射時における吸収線量を求 めるための係数、を得る方法を検討した結果, 良好で あった。

\section{（座長集約）成沢 順（国立仙台病院）}

このグループどは，装置に関するすの 2 題 $(9,10$, 体外計測に関するもの 3 題 $(11,12,13$,

治療 1 題(14)の発表が行われた。

9 席は, 臨床的に使用する機会の多い三種の異なる 線エネルギーについて, それぞれ計数率の統計的変動が 少なくなって高分解能を示すWindow 巾について 報告 した.

10席は，コリメーターの特性測定は，Point Sourceと， Line Source について，コリメーターを固定した場合と 移動させた場合の特性の変化を M. T. F により表わし たものである。

この 2 題は，いずれも装置の特性を充分に把握して活 用する上に，有用な報告と思う。

11席の腎Scan 剂の検討は, 近年開発された ${ }^{99 \mathrm{~m} T c-}$ gluconate $\check{2}^{99 \mathrm{~m} T c-D M S A}$ (Dimercaptosuccinicacid)

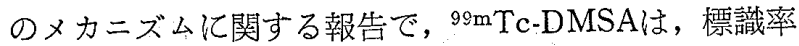
がよく安定で診断に有用であると述べている.しかし， 今後, 両者の機能的診断と, 形態的診断の有用性の比較 とか，腎機能低下症に対する適用についてす数多くの症 例により検討することが必要と思われる。

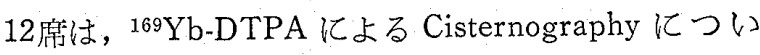
ては，てれまでも多くの発表が行われた．Liquorの標準 速度がはっきりしていない現在では， ${ }^{169} \mathrm{Yb}$ も有用な場 合ああるが，やはり問題となるのは，沫染物の処理であ ろう。

1970年 4 月，松村 (静岡労災) 等は，半減期の点加ら， 今後， ${ }^{111}$ In-DTPAを使用すべきであると結論付けてい る:

13 席は，テクネシウム燐酸化合物である， ${ }^{99 \mathrm{~m} T \mathrm{~T}-}$ Diphosphonate と, ${ }^{99 \mathrm{~m} T \mathrm{~T}-P y l o p h o s p h a t e}$ を用いて, 鮮 明な全身骨シンチグラムを得るべく検討されたもので，

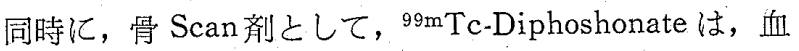
中消失の早さ，標識率，安定性と屯にすぐれている点も 追試している，骨における今後の問題は，症例のみなら ず，標準的集積機構を解明することにあると思う。

14席は，リアニックによる切線照射の際に，い汃にし て正確な吸収線量を測定（算出）し，且つ，均等な線量 分布を得て治療效果を高めるかという問題に対して，ひ
とつの指針を示したあのとして, 今後の成果を期待した w.

ラジオアイソトープの研究は, ますます進歩し, 普及 してきているので多数の演題が期待されたが, 来春の東 北総会の準備にかかっているためであるうか，今回は， 5 施設 6 題と比較的少なかった。 今後は, 更にデーター 処理や, Invitro 関係の研究等も加えて, 本部会がより 発展されますととを希望します.

\section{5. 胃集検時の被検者被曝線量について}

秋田県成人病予防協会

○金田 進 増子 宏
近藤 満 武田 政治
楼庭

本年度購入した胃集検者 $12^{\prime \prime} \phi$ HRII 間接撮影装置（東 芝製）を使用して，被検者の被曝線量について検討し た: ファントム MixDp $20 \mathrm{~cm}$ を用いて, 管電圧, フィ ルターの変化による被検体の空中線量を測定し, こラ 一間接之比較する. I. I. 間接の被曝線量は，え.ラ一間 接を 1 とした場合，撮影及び透視の総合比は約 $1 / 12$ とな り, $2 \mathrm{mmAl}$ フィルターを附加する事により更に約 $1 / 21$ に軽減できた。

$12 " \nu$ HRII を使用する事により，ミラ一間接に比較し

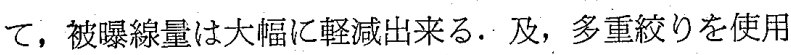
する事により，更に軽減出来る．ミラ一間接に比べ管球 容量に対する負荷が少なく，附加フィルターの選択によ り更に線量軽減が可能となった。

\section{6. 妊婦撮影時に於ける被曝軽減の一考察}

$\begin{array}{rrrr}\text { 秋田赤十字病院放射線科 } & & \\ \text { O米持 松雄 } & \text { 伊藤 } & \text { 正 } \\ \text { 矢嶋 } & \text { 克己 } & \text { 山本 } & \text { 務 } \\ \text { 岩田 } & \text { 良二 } & \text { 太田 } & \text { 重吉 } \\ \text { 中西 } & \text { 一秀 } & & \end{array}$

[目的]

妊婦の胎児撮影飞「極光New-SS」「Fuji RX-S」を組 み合わせ，どの程度まで胎児被曝線量を軽減できるか奏 験してみた。

[方法及び結果]

平均妊婦腹厚（腹臥位時にお打る）である $26 \mathrm{~cm}$ の水 ファントムを用い，ファントムの中心にラドコンのプロ ーブを挿入し，胎呪被暴線量を测定してみた。

測定結果から管電圧が80 90kVで胎児の被曝線量が 最小になることがわかった。

また，徒来，我々が使用していた MSのスクリーン， Fuji RX, ブッキーの組合せによる撮影時の胎児被曝線 
量を, New-SS のスクリーン, Fuji RX-S, $5: 1$ (34本/ $\mathrm{cm})$ のリスホルムブレンデ， $80 \mathrm{kV}$ の電圧の組合せに より約 $1 / 8$ 亿軽減することが出来た.

\section{（座長集約） 佐藤 重雄（鶴岡市立荘内病院）}

全発表を通じて先ず感じた事は，年毎に高度なテーマ 揃いの発表であり，技術分野として当然乍らも感服の他 なく，老いたる小生如き技師向，一歩一歩追って行かね ばならない現在の鴊りのない心境でした。

又, 担当セクションなる被曝では, 免角, 外勤伯追わ れて忙しい立場にあり乍らあ，「胃集検時の被検者被嚗 線量について」金田進技師の舊励痕跡と努力，又，院内 えの繁忙な勤務の合間にも，被検者に対して如何に被曝 を極力軽減し，且つ診断亿価值ある写真を提供し，丽撮 影等なく, 特に妊婦撮影飞於ける被嚗は, 誰しも知る如 く被曝量は他の部位化比して多いので, 其の慎重さと相 まっての研究テーマを御発表された米持松雄技師等, 我 我同僚技師の䛴りに思いました。

尚, 坐長席よりも申し上げましたが, 篠畸教授の御講 演でもお聞きなられた様に，今や被懪軽減問題につきま しては，国際的にあクローズアップされて抢り，実際に 放射線を受ける被検者之，又，放射線を直接取扱い，生 み出す我々技師として，今後一㬝，人類相互に於汸る被 懪問題に関して，集中，研鐟努力を期待致し度いあの之 思い, 今発表に対し，各演者の抄録に随言し，御報告芳 々集約と致します。

\section{7. 各種ファントムの比較について (第】報)}

青森県立中央病院放射線科

○福村 昭美 鎌田 光朗
相沢 正明 楼庭 昇一
今岡 淳一

[目的]

日本放射線技術学会ファントム委員会で作成されたフ ァントムと, 従来のファントム, 及び人体ファントムの 散乱線の測定をし，比較しました。

[方法]

ファントム中心より $1 \mathrm{~m} 08$ ケ所を, 電流, 時間を一 定にし，電圧を変えて測定しました。

〔結果〕

従来のファントムは，少ない值を示しました．人体フ ァントムは，頭部より大腿上部まで連続しているために， 頭足方向に少ない測定值を示しましたが，他の点では， JIS ファントムに近い測定值を示しました。これは，各 電压レベルに扔いても変らず同様でした．以上のととか ら, JIS ファントムは，人体ファントムに代わり十分散
乱線測定に使用できるすのと思われます。

\section{8．X線装置に於ける曝射時間の精度試験}

秋田大学病院放射線部

○鎌田 良二 畑山崇
佐々木宗逸 石郷 岡円
三浦 初男

$\mathrm{X}$ 線装置の高出力化, 感光材料の改良等により, 大線 量短時闆撮影が行われ正確なタイマー精度が要求されま す.我々は，当院において使用中の装置管理を目的に， $\mathrm{X}$ 線曝射時間計之, シンクロスコープを使用し, タイマ 一の動作状態を測定した．単相装値では，曝射時間の精 度だけでなく投入位相のズレのため波形の柾み，サージ 電圧等の調整不良が，直接出力に影響し，多相装置の場 合は特に測定器の性質上，管電圧の変動による影響が大 きく, 出力線量屯变り写真効果に影響するものと思われ た。曝射時間計の問題点として, 投入位相, 電源電圧, 管電流等の変動によって表示む変り，晎常值があっても， タイマー自体の不良とは限らない。

19. オート附加フイルターの試作（その2）

新潟県厚生惪中央総合病院

○目黑正誠

附加フィルターを使用して, X線写真に不必要な軟X 線をカットする事により, 患者の被嚗線量が軽減する事 は知られている。

今回, 消化管透視撮影装置が ICRP の勧告する総滤 過值になる様にフィルターを附加する事にした。透視時 は管球の負荷とモニターテレビの輝度等によって無理な ので，撮影時のみ撮影管電庄に応じ， $0.1 \mathrm{~mm} \mathrm{Cu}+$ $1 \mathrm{mmAl}$ と, $0.2 \mathrm{mmCu}+2 \mathrm{mmAl} の 2$ 種類の附加フィ ルターが働くようにした。その結果，撮影時に皮膚線量 で50\%の減少率を得た。簡単な装置によって皮膚線量で はあるが，約50\%向の被曝軽減になるので，むつ之進ん で附加フィルターを用いてすらいたいと思います。

\section{（座長集約）伊藤 陸郎（福島医大病院）}

演題17. 従来の箱形水ファントムと JIS ファントムと 人骨入ファントムを使用しての線量分布を比較したもの で，JIS ファントムが更に人骨入ファントムに近ずいて いる．頭足方向においてなお数値差はあるが，形状によ る屯のであり，日常測定の参考となろう。

演題18、X線装置のタイマーの精度不良による写真の 濃度不揃いは，瞬時撮影の場合，たまたま経験する事で ある，血管撮影の様认高電流短時間撮影装置では，設㯰 時は勿諭, 定期的な保守管理が特に必要である.

演題19. 透視撮影装置での患者被曝量は，かなりの数 